\title{
The Model State Emergency Health Powers Act: Public Health and Civil Liberties in a Time of Terrorism
}

Lawrence O. Gostin

Follow this and additional works at: https://scholarlycommons.law.case.edu/healthmatrix

Part of the Health Law and Policy Commons

\section{Recommended Citation}

Lawrence O. Gostin, The Model State Emergency Health Powers Act: Public Health and Civil Liberties in a Time of Terrorism, 13 Health Matrix 3 (2013)

Available at: https://scholarlycommons.law.case.edu/healthmatrix/vol13/iss1/4 


\title{
THE MODEL STATE EMERGENCY HEALTH POWERS ACT:
}

\section{PUBLIC HEALTH AND CIVIL LIBERTIES IN A TIME OF TERRORISM•}

\author{
Lawrence O. Gostin ${ }^{\dagger}$
}

- This Commentary is based on: Lawrence O. Gostin, Public Health Law in an Age of Terrorism: Re-thinking Individual Rights and Common Goods, 21 HEALTH AfFaIRS 79 (2002); Lawrence O. Gostin, Jason W. Sapsin, Stephen P. Teret et al., The Model State Emergency Health Powers Act: Planning for and Response to Bioterrorism and Naturally Occurring Infectious Diseases, 288 JAMA 622 (2002). For an examination of the conceptual approach to public health and civil liberties, see lawrence O. Gostin, Public Health law: Power, Duty, Restraint (2000); LaWrence O. Gostin, Public Health Law And Ethics: A Reader (2002), available at http://www.publichealthlaw.net/Reader/toc.htm.

Disclaimer and Acknowledgment: Cooperative Agreement Number U50/CCU31911802 from the CDC supports the Center for Law and the Public's Health at Georgetown and Johns Hopkins Universities. The author gratefully acknowledges the intellectual contributions of many organizations, notably the National Governors Association, National Conference of State Legislatures, National Association of Attorneys General, Association of State and Territorial Health Officials, and National Association of City and County Health Officials. The contents of this article are solely the responsibility of the author and do not necessarily represent the official views of the CDC or the organizations providing assistance in the development of the model act. The Alfred P. Sloan Foundation provided funding for the development of MSEHPA. The Reforming States Group, comprised of leaders of the legislative and executive branches, in collaboration with the Milbank Memorial Fund, provided technical assistance to many states. MSEHPA grew out of the work of the Public Health Statute Modernization National Collaborative of the Robert Wood Johnson Foundation (Turning Point). The Public Health Law Program at the CDC offered critical contributions throughout, particularly Richard Goodman and Gene Matthews. The drafting team for the Model Act, in addition to the author, included: Scott Burris, James G. Hodge, Jr., Julie Samia Mair, Jason W. Sapsin, Stephen P. Teret, and Jon Vernick. Jason W. Sapsin and Elizabeth Geddes provided helpful comments on this manuscript.

† Lawrence O. Gostin is Professor of Law, Georgetown University; Professor of Public Health, the Johns Hopkins University; and Director, Center for Law and the Public's Health (CDC Collaborating Center Promoting Health Through Law). He is a Research Fellow at the Centre for Socio-Legal Studies, Oxford University. Professor Gostin, a lifetime member of the Institute of Medicine, is on the IOM Board on Health Promotion and Disease Prevention and the IOM Committee on the Future of the Public's Health in the $21^{\text {st }}$ Century. 
Safeguarding the public's health, safety, and security took on new meaning and urgency after the attacks on the World Trade Towers in New York and the Pentagon in Washington, D.C. on September 11, 2001. On October 4, 2001, a Florida man named Robert Stevens was diagnosed with inhalational anthrax. ${ }^{1}$ The intentional dispersal of anthrax through the U.S. postal system in New York, Washington, Pennsylvania and other locations resulted in five confirmed deaths, hundreds treated, and thousands tested. ${ }^{2}$ The potential for new, larger, and more sophisticated attacks have created a sense of vulnerability. National attention has urgently turned to the need to rapidly detect and react to bioterrorism, as well as to naturally occurring infectious diseases.

In the aftermath of September $11^{\text {th }}$, the President and the Congress began a process to strengthen the public health infrastructure. ${ }^{3}$ The Center for Law and the Public's Health (CLPH) at Georgetown and Johns Hopkins Universities drafted the Model State Emergency Health Powers Act ("MSEHPA or the "Model Act") at the request of Centers for Disease Control and Prevention (CDC) and in collaboration with members of national organizations representing governors, legislators, attorneys general, and health commissioners. Because the power to act to preserve the public's health is constitutionally reserved primarily to the states as an exercise of their police powers, ${ }^{5}$ the

1 Larry M. Bush et al., Index Case of Fatal Inhalational Anthrax Due to Bioterrorism in the United States, 345 NEw ENG. J. MED. 1607, 1607 (2001) (detailing the hospitalization of the patient); see also John A. Jernigan et al., BioterrorismRelated Inhalational Anthrax: The First 10 Cases Reported in the United States, 7 EMERGING INFECTIOUS DISEASES 933, 934 (2001) (explaining the medical indications and treatment for ten cases of anthrax).

2 See Daniel B. Jernigan et al., Investigation of Bioterrorism-Related Anthrax, United States, 2001: Epidemiologic Findings, 8 EMERGING INFECTIOUS DISEASES 1019, $1019 \quad$ (2002), available at $\mathrm{http} / / / \mathrm{www} . c d c . g o v / \mathrm{ncidod} / \mathrm{eid} / \mathrm{vol} 8 \mathrm{no} 10 / 02-0353 . \mathrm{htm}$ (noting that there were five fatalities as a result of the recent anthrax scare); see also Morton N. Swartz, Recognition and Management of Anthrax - An Update. 345 NEW ENG. J. MED. 1621, 1621 (2001), available at http://www.nejm.org (summarizing anthrax problem of 2001).

${ }_{3}^{3}$ See Office of Mgmt. And Budget, Executive Office of the President, Budget of the United States Government, Fiscal Year 2003: Protecting the Homeland $\quad 15, \quad 19 \quad(2002), \quad$ available at http://www.whitehouse.gov/omb/budget/fy2003/pdf/bud05.pdf (proposing to spend " $\$ 1.2$ billion in 2003 to increase the capacity of state and local health delivery systems to respond to bioterrorism attacks").

${ }_{4}^{4}$ The Model State Emergency Health Powers Act (The Ctr. for Law and the Pub.'s Health at Georgetown and Johns Hopkins Univs., Proposed Draft 2001), available at http://www.publichealthlaw.net (last visited Nov. 13, 2002).

5 E.g., Lawrence O. Gostin, Public Health Law: Power, Duty, Restraint 47 (Univ. of Cal. Press 2000) (discussing constitutional authorization to 
Model Act is designed for state - not federal - legislative consideration. It provides responsible state actors with the powers they need to detect and contain a potentially catastrophic disease outbreak and, at the same time, protects individual rights and freedoms. Thirty-six states and the District of Columbia have introduced legislative bills based on the MSEHPA; thirty-nine states and the District of Columbia have enacted or are expected to shortly enact a version of the Model Act. $^{6}$

Despite its success in many states, the Model Act has become a lightening rod for criticism from both ends of the political spectrum. ${ }^{7}$ It has galvanized public debate around the appropriate balance between personal rights and common goods. ${ }^{8}$

In this Commentary, I first offer a brief context for understanding bioterrorism and naturally occurring infectious diseases - their history and challenges. This background demonstrates the vast potential for serious harm to the population. Next, I examine the state of infectious disease law among the states. Infectious disease law in the United States is riddled with problems, including its antiquity, inconsistency, barriers to effective action, and absence of safeguards of personal liberty. Third, I describe two national efforts for law reform: the

protect the common good).

${ }^{6}$ As of April 21, 2003, states enacting or expected shortly to enact legislation influenced by the Model Act were Arizona, Delaware, Florida, Georgia, Hawaii, Maine, Maryland, Minnesota, Missouri, New Hampshire, New Mexico, North Carolina, Oklahoma, Pennsylvania, South Carolina, South Dakota, Tennessee, Utah, Vermont, Virginia, Wisconsin, and Wyoming. Other states that have introduced legislation based on the Model Act were California, Connecticut, Idaho, Illinois, Kansas, Kentucky, Massachusetts, Mississippi, Nebraska, New Jersey, New York, Ohio, Pennsylvania, Rhode Island, Washington, and Wyoming. Center for Law and the Public's Health at Georgetown and Johns Hopkins Universities, The Model State Emergency Health Powers Act State Legislative Activity, at http://www.publichealthlaw.net/MSEHPA/MSEHPA_Leg_Activity_050102. pdf (last modified Oct. 1, 2002). See also Justin Gillis, States Weighing Laws to Fight Bioterrorism, WASH. POST, Nov. 19, 2001, at Al (discussing the antiquated nature of existing state public health laws); Sarah Lueck, States Seek to Strengthen Emergency Powers: Movement Is Raising Privacy and Civil-Liberties Concerns, WALL ST. J., Jan. 7, 2002, at A26.

7 See Ronald Bayer \& James Colgrove, Public Health vs. Civil Liberties, 297 SCIENCE 1811, 1811 (2002) (describing the criticism in response to the first and second draft of the Model Act raised by AIDS advocates, physicians, hospitals, antivaccination advocates, privacy advocates, and civil liberties advocates).

${ }^{8}$ See, e.g., George J. Annas, Bioterrorism, Public Health, and Civil Liberties, 346 NEw ENG. J. MED. 1337 (2002), available at http://www.nejm.org (arguing that civil liberties do not necessarily have to be sacrificed even in a public health emergency). 
"Turning Point" Model Public Health Act and the Model Emergency Health Powers Act. The Turning Point Model Public Health Law, due for completion in late 2003, will state the missions, functions, and powers of public health agencies in the twenty first century. The Model Emergency Health Powers Act is designed to provide special powers to rapidly identify and respond to bioterrorism or a naturally occurring infectious disease that poses a grave immediate threat to the population. Fourth, I offer a defense of MSEHPA, by first describing the drafting process and then, outlining and responding to the main objections of critics. In particular, I respond to arguments relating to federalism, emergency declarations, abuse of power, personal libertarianism, economic libertarianism, and safeguards of property and persons. I conclude with some reflections about individual interests and common goods in America. Our culture during the latter part of the twentieth century has been highly individualistic, stressing the importance of the autonomous person and the undeterred entrepreneur. Certainly, these values have served America well in enhancing personal freedoms and contributing to a thriving economy. However, we have lost a sense of community and inter-relatedness that are equally vital to human well-being. Without protection of health, safety and security, people cannot enjoy many of the personal and economic freedoms that we have come to take for granted. ${ }^{9}$

\section{BACKGROUND}

Both naturally occurring infectious disease ${ }^{10}$ and bioterrorism pose threats to public health. Historically, major naturally occurring infectious disease outbreaks have killed far more people than war: the bubonic plague in the $14^{\text {th }}$ century lead to the death of approximately 25 million Europeans, over a quarter of the population; ${ }^{11}$ diseases such as smallpox, tuberculosis, measles, influenza, typhus and bubonic plague killed an estimated $95 \%$ of pre-Columbian Native American

9 See, e.g., Dan E. Beauchamp, The Health of THE Republic: Epidemics, Medicine, And Moralism as Challenges to Democracy (1998); James F. Childress, et al., Public Health Ethics: Mapping the Terrain, 30 J.L., MED. \& ETHICs 170 (2002) (generally discussing how the pursuance of public health necessarily infringes on personal autonomy).

${ }^{10}$ Infectious diseases are diseases caused by a living organism or other pathogen, including a fungus, bacteria, parasite, protozoan, or virus, which may or may not be transmissible from person to person, animal to person, or insect to person.

11 See RoY M. ANDERSON \& RoberT M. MAY, INFECTIOUS DisEASES OF HumAN: DYNAMICS AND CONTROL, 1 (1992) (showing impact of bubonic plague on Europe). 
populations; ${ }^{12}$ and a worldwide influenza epidemic in 1918-1919 resulted in the death of 21 million people. ${ }^{13}$ While naturally occurring infectious disease may no longer be the leading cause of death in the United States because of advancements in hygiene, nutrition and medicine, the death toll is still substantial. ${ }^{14}$ Each year approximately 170,000 Americans die from infectious diseases. ${ }^{15}$ Emerging or resurgent diseases ${ }^{16}$ such as West Nile Virus ${ }^{17}$ pose modern threats to America's health. ${ }^{18}$ A report by the National Intelligence Council for the Central Intelligence Agency concluded that infectious disease is not only a public health issue, but also a problem of national security: the U.S. population is vulnerable to bioterrorism as well as emerging and reemerging infectious diseases. ${ }^{19}$

Preventing major disease outbreaks poses as great a challenge as ever before. The globalization of travel and trade allows for the widespread, rapid transmission of disease. Even though infectious disease is no longer a leading cause of death in the United States, internationally, infectious disease continues to be a leading cause of death. ${ }^{20} \mathrm{~A}$

12 Jared Diamond, Guns, Germs, and Steel: The Fates of Human SOCiETIES 211-12 (1999). For a discussion of the prevalence of tuberculosis in human history, see Lawrence O. Gostin, The Resurgent Tuberculosis Epidemic in the Era of AIDS: Reflections on Public Health, Law, and Society, 54 MD. L. REV. 1 (1995).

${ }_{13}$ Bradley N. Doebbeling, Influenza, in MAXCY-Rosenau-LAST PUBLIC Health \& Preventive Medicine 107, 108 (Robert B. Wallace ed., $14^{\text {th }}$ ed. 1998).

${ }_{14}$ See Robert N. Anderson, Deaths: Leading Causes for 1999, 49 NAT'L VITAL STAT. REP. 1, 1 (Oct. 2001), available at http://www.cdc.gov/nchs/data/nvsr/nvsr49/nvsr49_11.pdf (compiling cause of death information and finding infectious diseases are no longer a top cause of deaths in the United States).

${ }^{15}$ NAT'L. Intelligence COUNCIL, THE Global INFECTIOUS DisEaSe Threat AND ITS IMPLICATIONS FOR THE UNITED STATES, NIE 99-17D (Jan. 2000), at http://www.cia.gov/cia/publications/nie/report/nie99-17d.html (noting that "[a]nnual infectious disease-related death rates in the United States have nearly doubled to some 170,000 annually after reaching an historic low in 1980").

${ }^{16}$ See, e.g., Mary E. Wilson, Infectious Diseases: An Ecological Perspective, 311 BRIT. MED J. 1681 (1995), available at http://bmj.com (describing how today's socioeconomic, political, environmental, and climatic states are leading to the resurgence of infectious diseases).

${ }_{17}$ In 2002, over 2500 cases of West Nile virus in humans have been reported to the CDC, with 125 fatalities thus far. Press Release, Centers for Disease Control and Prevention, West Nile Virus Update (Oct. 3, 2002), at http://www.cdc.gov/od/oc/media/pressrel/r021003.htm.

18 The threat to the public's health from infectious diseases is exacerbated by antibiotic resistance to standard medications. See, e.g., Stuart B. Levy, Antibiotic Availability and Use: Consequences to Man and His Environment, 44 J. CLINICAL EPIDEMIOLOGY 83S, 83S (1991).

19 NAT'L INTELLIGENCE COUNCIL, supra note 15.

${ }^{20}$ Wilson, supra note 16 , at 1681 (stating that infectious diseases are still the 
person infected in Hong Kong can travel to the United States in less than a day. Large concentrations of people also facilitate the spread of disease, and many cities have populations in the millions. Even in contemporary societies human populations remain in close proximity to animal populations. Some of the most deadly human diseases are believed to have evolved from animal diseases.

In addition to the threat of severe, naturally occurring infectious diseases, recent events highlight the threat of bioterrorism. Bioterrorism is the intentional use of a pathogen or biological product to cause harm to a human, animal, plant, or other living organism to influence the conduct of government or to intimidate or coerce a civilian population. This risk of bioterrorism is severe and the results could be devastating. In 1999, the U.S. Commission on National Security in the $21^{\text {st }}$ Century concluded that biological agents are the most likely choice of weapons for disaffected states and groups. ${ }^{21}$ Biological weapons are nearly as easy to develop, will likely become easier to deliver, and are far more lethal than chemical weapons; ${ }^{22}$ and, unlike nuclear weapons, biological weapons are inexpensive to produce and the risk of detection is low. ${ }^{23}$

While experts have long been calling attention to the threat of bioterrorism and the unique problems that arise in modern society, ${ }^{24}$ technological advances even further amplify this threat. For example,

leading single cause of death in the world).

${ }^{21}$ U.S. Comm'n on Nat'l Sec. 21st Century, New World COMING: AMERICAN SECURITY IN THE 21 ST CENTURY: SUPPORTING RESEARCH AND ANALYSIS: THE PHASE I REPORT ON THE EMERGING GLOBAL SECURITY ENVIRONMENT FOR THE FIRST QUARTER OF THE $21^{\text {sT }}$ CENTURY 50 (1999).

${ }_{22}$ In 1993, the U.S. Congressional Office of Technology Assessment estimated that the aerosolized release of $100 \mathrm{~kg}$ of anthrax spores upwind of Washington, DC could result in approximately 130,000 to 3 million deaths, a weapon as deadly as a hydrogen bomb. Thomas V. Inglesby et al., Anthrax as a Biological Weapon: Medical and Public Health Management, 281 JAMA 1735, 1736 (1999), available at http://www.jama.ama-assn.org/issues/v281n18/ffull/jst80027.html.

${ }^{23}$ U.S. Comm'n on Nat'l Sec. $/ 21$ st Century, supra note 21 , at 50.

${ }^{24}$ See James M. Hughes, The Emerging Threat of Bioterrorism, 5 EMERGING INFECTIOUS DISEASES 494 (1999), available at $\mathrm{http} / / \mathrm{www} . c \mathrm{cdc} . g o v / n c i d o d / e i d /$ (explaining challenges of national and local preparedness in the face of a potentially large geographic dispersion of the microbial agent during its inoculation period); Donald A. Henderson, The Looming Threat of Bioterrorism, 283 SCIENCE 1279, 1279-91 (1999) (explaining the history of the threat of bioterrorism); Thomas V. Inglesby, et al., Preventing the Use of Biological Weapons: Improving Response Should Prevention Fail, 30 ClINICAL INFECTIOUS DiSEASES 926, 926-28 (2000), available at $\mathrm{http} / / \mathrm{www}$.journals.uchicago.edu/CID/journal/home.html (explaining the increasing danger of a bioterrorist attack and the steps that can be taken to minimize its consequences); Leonard A. Cole, The Specter of Biological Weapons, SCI. AM. Dec. 1996, at 60, 62-63 (noting the widespread development of biological weapons). 
the Internet, which allows for the widespread dissemination of information on biological agents and technology, and advancements in biotechnology make bioproduction capabilities accessible to individuals with limited experience. The dual use nature of this knowledge and technology - allowing for both legitimate and illicit use - makes tracking and identifying bioterrorists much more difficult. And while certain countries are known or suspected to have biological weapons programs, non-state actors have become important as well. Documents recovered in Afghanistan suggest that $\mathrm{Al}$ Qaeda has conducted extensive research on weapons that can cause mass fatalities, including biological weapons. ${ }^{25}$

Government and public health officials must be able to react quickly and intelligently to a potentially catastrophic disease outbreak, whether intentionally instigated (i.e., bioterrorism) or naturally occurring. Two exercises, Dark Winter (smallpox) ${ }^{26}$ and TOPOFF (plague), ${ }^{27}$ simulated biological attacks in the United States to test government response and raise awareness of the bioterrorism threat. Both simulations demonstrated serious weaknesses in the U.S. public health system that could prevent an effective response to bioterrorism $^{28}$ or severe, naturally occurring infectious diseases. ${ }^{29}$ The federal government intends to repeat these modeling exercises to test whether increased preparedness since September $11^{\text {th }}$ will result in a more efficient response to bioterrorism.

${ }^{25}$ Robert Cottrell, Safe Houses Yielding Documents on Weapons of Mass Destruction, Fin. TIMES, Nov. 23, 2001.

${ }_{26}$ Tara O'Toole, Shining Light on "Dark Winter", 34 CLINICAL INFECTIOUS DISEASES 972, $972 \quad$ (2002), available at http://www.journals.uchicago.edu/CID/journal/issues/v34n7/020165/020165.html (reporting results of a simulation of National Security Council meetings in response to a small pox outbreak in three states).

${ }_{27}$ Thomas V. Inglesby et al., A Plague on Your City: Observations from TOPOFF, 32 CLINICAL INFECTIOUS DISEASES 436 (2001), available at http://www.journals.uchicago.edu/CID/journal/issues/v32n3/001347/001347.html (reporting the results and lessons learned from a simulation of a bioweapons attack).

${ }^{28}$ See Joseph Barbera, Anthony Macintyre, Larry Gostin et al., Large-Scale Quarantine Following Biological Terrorism in the United States: Scientific Examination, Logistic and Legal Limits, and Possible Consequences, 286 JAMA 2711, 271315 (Dec. 5, 2001), available at http://jama.amaassn.org/issues/v286n21/ffull/jsc10254.html (noting that large scale, hastily implemented quarantines often have unintended adverse consequences).

${ }^{29}$ See The Threat of Bioterrorism and the Spread of Infectious Diseases: Hearing Before the Committee on Foreign Relations United States Senate, 107th Cong. 62-70 (2001) (testimony of Donald A. Henderson), available at http://www.access.gpo.gov/congress/senate/senate11sh107.html. 


\section{THE NEED FOR LAW REFORM}

Law has long been considered an important tool of public health. ${ }^{30}$ Although federal law-making authority is constitutionally limited in scope, states have more flexibility in legislating to protect the public's health as an exercise of their broader police powers. State public health laws create a mission for public health authorities, assign their functions, and specify the manner in which they may exercise their authority. ${ }^{31}$ Prior to September 11, 2001, some states had legislatively (e.g., Colorado) ${ }^{32}$ or administratively (e.g., Rhode Island) ${ }^{33}$ developed public health response plans for a bioterrorism event. However, problems of obsolescence, inconsistency, and inadequacy may render some public health laws ineffective, or even counterproductive. ${ }^{34}$ Reforming state public health law can improve the legal infrastructure to help respond to bioterrorism and other emerging threats.

Many state public health statutes were built up in layers during the twentieth century in response to each new disease threat. These outdated laws often do not reflect contemporary scientific understandings of disease (e.g., surveillance, prevention, and response). When many of these statutes were written, public health sciences such as epidemiology and biostatistics were in their infancy and modern prevention and treatment methods did not exist.

At the same time, many existing public health laws pre-date the vast changes in constitutional (e.g., equal protection and due process) and statutory (e.g., disability discrimination) law that have transformed social and legal conceptions of individual rights. Consequently, these laws do not reflect legal norms for protection of individual rights. Failure to reform these laws may leave public health authorities vulnerable to legal challenge on grounds that they are unconstitutional or preempted by modern federal statutes. Even if state

${ }^{30}$ See generally LaWrence O. Gostin, Public Health Law and ETHICS: A READER (2002).

${ }^{31}$ See Lawrence O. Gostin, Public Health Law Reform, 91 AM. J. PUB. HEALTH 1365 (2001).

${ }^{32}$ Colo. Rev. Stat. Ann. §§ 24-32-2103, 2104 (2001).

${ }^{33}$ R.I. Dep't of Health, Bioterrorism Preparedness Program, at http://www.healthri,org/environment/biot/home.htm (describing a program funded by the CDC in 1999 to expand and upgrade the ability of Rhode Island to detect and respond to biological and chemical agents and to provide a public health response to terrorist acts in the United States) (last visited Nov. 13, 2002).

${ }^{34}$ See Lawrence O. Gostin et al., The Law and the Public's Health: A Study of INFECTIOUS Disease LAW IN THE UNITED STATES, 99 COLUM. L. Rev. 59, 101-17 (1999). 
public health law is not challenged in court, public health authorities may feel unsure about applying old legal remedies to modern health threats.

Health codes among the fifty states and territories have evolved independently, leading to profound variation in the structure, substance, and procedures for detecting, controlling, and preventing disease. Ordinarily different state approaches are not a problem, but variation could prevent or delay an efficient response in a multi-state public health emergency. Infectious diseases are rarely confined to single jurisdictions, but pose risks within whole regions or the nation itself. Coordination among state and national authorities is vital, but is undermined by disparate legal structures.

Public health laws remain fragmented within states as well as among them. Most state statutes have evolved over time so that, even within the same state, different rules may apply depending on the particular disease in question. This means that necessary authority (e.g., screening, reporting, or compulsory treatment) may be absent for a given disease. For example, when a resurgence of multi-drug resistant tuberculosis swept major metropolitan areas in the 1990s, many statutes did not allow for directly observed therapy. ${ }^{35}$ Worse still, state laws can be so complex that they may not be well understood by health practitioners or their attorneys, preventing practitioners from acting rapidly and decisively in an emergency.

Many current laws not only provide insufficient authority to act, but might actually thwart effective action. This is evident when one examines the key variables for public health preparedness: planning, coordination and communication, surveillance, management of property, and protection of persons.

State statutes generally fail to require planning or to establish mechanisms. As a result most states have not systematically designed a strategy to respond to public health emergencies. Perhaps the most important aspects of planning are clear communication and coordination among responsible governmental officials and the private sector. As the recent anthrax outbreaks demonstrate, ${ }^{36}$ there should be a defined role for public health, law enforcement, and emergency management agencies. So too, should there be coordination among the

${ }^{35}$ Comm. on the Elimination of Tuberculosis in the U.S., Inst. of Med., Ending Neglect: The Elimination of Tuberculosis in the United States (Lawrence Geiter, ed., 2000), available at http://www.nap.edu/books/0309070287/html.

${ }^{36}$ See H. Clifford Lane \& Anthony S. Fauci, Bioterrorism on the Home Front: A New Challenge for American Medicine, 286 JAMA 2595, 2596 (2001) (noting the importance of "rapid dissemination of reliable, up-to-date information" to successfully meet the challenges presented by anthrax). 
various levels (e.g., federal, tribal, state, and local) and branches (legislative, executive, and judicial) of government as well as with private actors, particularly the health care and pharmaceutical sectors. A systematic planning process that involves all stakeholders improves communication and coordination. The law can require such planning and sharing of information. However, many public health statutes do not facilitate communication and, due to federal and state privacy concerns, may actually proscribe exchange of vital information among public health, law enforcement, and emergency management agencies. Indeed, some statutes even prohibit sharing data with public health officials in adjoining states by strictly limiting disclosures by the public health agency that holds the data, often in the interest of protecting individual privacy. ${ }^{37}$ Laws that complicate or hinder data communication among states and responsible agencies would impede a thorough investigation and response to such a public health emergency.

Surveillance is critical to public health preparedness. Unlike most forms of terrorism, the dispersal of pathogens may not be evident. Early detection could save many lives by triggering an effective containment strategy such as vaccination, treatment and, if necessary, isolation or quarantine. However, current statutes do not facilitate surveillance and may even prevent monitoring. For example, many states do not require timely reporting for certain dangerous ("Category A") agents of bioterrorism such as smallpox, anthrax, plague, botulism, tularemia, and viral hemorrhagic fevers. ${ }^{38}$ In fact, virtually no state requires immediate reporting for all the critical agents identified by the Centers for Disease Control and Prevention. ${ }^{39}$ At the same time, states do not require, and may actually prohibit, public health agencies from monitoring data collected in the health care system. Private information that might lead to early detection (e.g., unusual clusters of fevers or gastrointestinal symptoms) held by hospitals, managed care organizations, and pharmacies may be unavailable to public health officials. New federal health information privacy protections may unintentionally impede the flow of data from private to

${ }^{37}$ See Lawrence O. Gostin et al., The Public Health Information Infrastructure: A National Review of the Law on Health Information Privacy, 275 JAMA 1921, 1925 (1996) (surveying the protection of public health data collected by states).

${ }^{38}$ See Lisa D. Rotz et al., Public Health Assessment of Potential Biological Terrorism Agents, 8 EMERGNG INFECTIOUS DISEASES (Feb. 2002), available at http://www.cdc.gov/ncidod/EID/vol8no2/01-0164.htm (explaining the classification process of critical biological agents for public health preparedness).

${ }^{39}$ See Heather H. Horton H et al., Critical Biological Agents: Disease Reporting as a Tool for Bioterrorism Preparedness, 30 J. L., MED. \& ETHICs 262, 264 (2002) (noting that virtually no state requires reporting of all 24 critical biological agents identified by the Centers for Disease Control and Prevention). 
public sectors despite regulators' attempt to broadly exempt public health information sharing from nondisclosure rules. ${ }^{40}$

Coercive powers are the most controversial aspects of any legal system. Nevertheless, they may be necessary to manage property or protect persons in a public health emergency. There are numerous circumstances that might require management of property in a public health emergency - e.g., shortages of vaccines, medicines, hospital beds, or facilities for disposal of corpses. It may even be necessary to close facilities or destroy property that is contaminated or dangerous. Even in the case of a relatively small outbreak, such as the recent anthrax attacks, the government considered the need to compulsorily license proprietary medications and destroy contaminated facilities. ${ }^{41}$ The law must provide authority, with fair safeguards, to manage property that is needed to contain a serious health threat.

There similarly may be a need to exercise powers over individuals to avert a significant threat to the public's health. Vaccination, testing, physical examination, treatment, isolation, and quarantine each may help contain the spread of infectious diseases. Although the vast majority of people probably will comply willingly (because it is in their own interests and/or desirable for the common welfare), some compulsory powers are necessary for those who will not comply. Provided those powers are bounded by legal safeguards, individuals should be required to yield some of their autonomy, liberty or property to protect the health and security of the community.

The view I have expressed, that public health law is outdated and needs to be reformed, is now well accepted. The Institute of Medicine (IOM), in its foundational 1988 report, The Future of Public Health, acknowledged that law was essential to public health but cast serious doubt on the soundness of public health's legal basis. Concluding that "this nation has lost sight of its public health goals and has allowed the system of public health activities to fall into disarray," the IOM

${ }^{40}$ See Lawrence O. Gostin \& James G. Hodge, Jr., Personal Privacy and Common Goods: A Framework for Balancing Under the National Health Information Privacy Rule, 86 MINN. L. REV. 1439, 1453 (2002) (noting that "public health authorities may not be able to share relevant data with law enforcement or emergency management agencies even in the event of bioterrorism" and "public health authorities may not be permitted to monitor health care data in hospitals, managed care organizations, and pharmacies, even though these data may provide an early warning of an infectious disease outbreak or bioterrorism").

${ }^{41}$ Ed Silverman \& David Schwab, U.S. Will Respect Cipro Patent - Feds Opt Not to Allow Copies of Antibiotic, THE STAR-LEDGER (Newark, NJ), Oct. 18, 2001 (noting that one U.S. Senator asked the White House to invoke a law that permits federal officials to both disregard a federal patent and issue a compulsory license to others companies). 
recommended reform of an obsolete and inadequate body of enabling laws and regulations. ${ }^{42}$ In its 2002 report, The Future of the Public's Health in the Twenty First Century, the IOM notes that little progress has been made in implementing its 1988 proposal. The committee recommends, "public health law be reformed so that it conforms to modern scientific and legal standards, is more consistent within and among states, and is more uniform in its approach to different health threats." $" 43$

The U.S. Department of Health and Human Services (HHS) in Healthy People 2010, similarly argued that strong laws are a vital component of the pubic health infrastructure and recommended that states reform their outdated statutes. ${ }^{44}$ The CDC, building on HHS' recommendation, advised, "all health departments [should] have sufficient public health laws and authorities to carry out the essential pubic health services." ${ }^{45}$ Indeed, the "overarching goal" of the public health component of the CDC Bioterrorism Preparedness Program is "to develop state and local public health systems' full legal preparedness." $" 46$

\section{THE TURNING POINT MODEL PUBLIC HEALTH ACT}

In response to a sustained critique of the crumbling public health infrastructure, the Robert Wood Johnson Foundation, in partnership with the W.K. Kellogg Foundation, initiated the "Turning Point project in 1996: "Collaborating for a New Century in Public Health." Turning Point launched five National Excellence Collaboratives in 2000, including the Public Health Statute Modernization Collaborative. The Collaborative's mission is "to transform and strengthen the legal framework for the public health system through a collaborative process to develop a model public health law."

\footnotetext{
${ }^{42}$ COMm. For the Study of the Future of PUb. Health, Inst. of Med., The Future of Public Health (1988).

${ }^{43}$ InSt. OF Med., The Future Of THE Public's Health IN THE TwENTY First CENTURY (forthcoming 2002).

44 See 2 U.S. Dep't of Health \& Human Servs., Healthy People 2010, 23-18 (2000), available at http://www.health.gov/healthypeople/document/tableofcontents.htm (noting the importance of a national model law).

${ }^{45}$ Ctrs. For Disease Control \& Prevention, Public Health's INFRASTRUCTURE: A STATUS REPORT, at V (2002), available at http://www.naccho.org/files/Infrastructure.pdf.

${ }^{46}$ Ctrs. for Disease Control \& Prevention, Public Health Legal PREPAREDNESS PROGRAM (July 17, 2002) (unpublished).
} 
The Public Health Statute Modernization Collaborative is led by a consortium of states, in partnership with federal agencies and national organizations. The collaborative contracted with the author to draft a model public health act under the guidance of a national expert committee. It has published a comprehensive assessment of state public health laws, demonstrating the inadequacies of existing law to support modern pubic health functions. ${ }^{47}$ The objective is to ensure that state public health law is consistent with modern constitutional principles and reflects current scientific and ethical values underlying public health practice. The Turning Point Model Public Health Act will focus on the organization, delivery, and funding of essential public health services and functions. It is scheduled for completion by October 2003 , and current drafts are available on the Internet. ${ }^{48}$

\section{THE MODEL STATE EMERGENCY HEALTH POWERS ACT}

The pace of completion of the Turning Point Model Public Health Act was too slow to meet political and social needs for increased security following September $11^{\text {th }}, 2001$. Consequently, the U.S. Department of Health and Human Services embarked on a rapid process to help the states improve their public health law infrastructure. ${ }^{49}$ The concept was to build a model that states could adapt to their own needs in a federalist system.

From a practical and political perspective, it is important that any model law draw its legitimacy from recognized sources of authority. The MSEHPA's theoretical foundations and structures are derived from: (1) existing federal or state law that offers model language; (2)

\footnotetext{
${ }^{47}$ Lawrence O. Gostin \& James G. Hodge, JR., State Public Health LAW ASSESSMENT REPORT 1-2 (Apr. 2002), available at http://turningpointprogram.org/Pages/PHSC_PH_statute_report_070302.pdf (noting that existing statutes often "(1) pre-date modern scientific and constitutional developments; (2) fail to equip public health officials with a range of flexible powers needed to control infectious disease; (3) do not address modern conditions which impact public health; (4) lack adequate standards of privacy, due process, and risk assessment; and (5) are based on arbitrary disease classification schemes that no longer relate to modern disease threats or epidemiologic methods of infection control").

48 The Model State Pub. Act (Turning Point Pub. Health Statute Modernization Nat'l Collaborative, Tentative Draft 2002), available at http://turningpointprogram.org/Pages/phsc_MSPH\%20Act3.pdf (May 31, 2002).

${ }^{49}$ See Press Release, Statement by HHS Secretary Tommy G. Thompson Regarding the Model Emergency Health Powers Act, Dep't Health \& Human Servs. (Oct. 30, 2001), available

at http://www.hhs.gov/news/press/2001 pres/20011030.html.
} 
lessons derived from theoretical exercises such as TOPOFF and Dark Winter; and (3) a meeting of high-level experts in public health, emergency management, and national security that took place at the Cantigny Conference Center in April, 2001..$^{50}$ The Center for Law and the Public's Health received comments on the Model Act from government agencies, national organizations, academic institutions, practitioners, and the general public. MSEHPA, therefore, expresses an attempted best synthesis of advice, recommendations, and dialogue regarding the purpose of emergency public health law, its proper reach, and the protection of civil liberties and private property. (See Table for an outline of the MSEHPA).

Table 1: Outline of Provisions Included in the Model Act

\begin{tabular}{|c|c|}
\hline ARTICLE I & Title, Findings, Purposes, and Definitions \\
\hline $\begin{array}{c}\text { ARTICLE } \\
\text { II }\end{array}$ & Planning for a Public Health Emergency \\
\hline $\begin{array}{c}\text { ARTICLE } \\
\text { III }\end{array}$ & $\begin{array}{c}\text { Measures to Detect and Track Public } \\
\text { Health Emergencies }\end{array}$ \\
\hline $\begin{array}{c}\text { ARTICLE } \\
\text { IV }\end{array}$ & Declaring a State of Public Health Emer- \\
gency \\
\hline $\begin{array}{c}\text { ARTICLE } \\
\text { V }\end{array}$ & $\begin{array}{c}\text { Special Powers During a State of Public } \\
\text { Health Emergency: Management of Property }\end{array}$ \\
\hline $\begin{array}{c}\text { ARTICLE } \\
\text { VI }\end{array}$ & $\begin{array}{c}\text { Special Powers During a State of Public } \\
\text { Health Emergency: Protection of Persons }\end{array}$ \\
\hline $\begin{array}{c}\text { ARTICLE } \\
\text { VII }\end{array}$ & Public Information Regarding Public \\
\hline ARTICLE & Mealth Emergency \\
VIII & Miscellaneous \\
\hline
\end{tabular}

The purpose of the MSEHPA is to facilitate the detection, management and containment of public health emergencies while appropriately safeguarding personal and proprietary interests. The Model Act gives rise to two kinds of public health powers and duties: Those that exist in the pre-emergency environment ("pre-declaration powers" found in Articles II and III) and a separate group of powers and duties that come into effect only after a state's Governor declares a

so The CTrs. For Disease Control \& Prevention, the AM. Bar Ass'N STANDING COMM. ON LAW aNd NaT'L SEC., THE NAT'L STRATEgY ForUM, THE Alfred P. Sloan Found, Cantigny Conference: State EMERgency Health POWERS \& THE BIOTERRORISM THREAT, Chicago, at http://www.nationalstrategy.com/april\%20conference.htm (Apr. 26-27, 2001). 
public health emergency (the "post-declaration powers" of Articles V, VI and VII). Post-declaration powers deliberately are broader and more robust.

Under Article IV, a Governor may declare a public health emergency only if a series of demanding threshold conditions are met: (1) an occurrence or imminent threat of an illness or health condition, that (2) is caused by bioterrorism or a new or re-emerging infectious agent or biological toxin previously controlled and that (3) also poses a high probability of a large number of deaths, a large number of serious or long-term disabilities, or widespread exposure to an infectious or toxic agent that poses a significant risk of substantial future harm to a large number of persons. Recognizing the continuing threat of infectious disease, the Model Act as drafted is not limited to bioterrorism emergencies: a mass epidemic could be sufficiently severe to trigger the Model Act's provisions even if naturally occurring provided that the infectious agent is novel or previously controlled. States may therefore choose to enhance and further strengthen the threshold conditions for invoking the Model Act, perhaps by including a requirement that the security, safety or normal operation of the State be threatened before an emergency may be declared. States may also choose an "all hazards" approach that adds chemical and nuclear threats to the biological threats contemplated by the Model Act. The MSEHPA requires the Governor to consult with the public health authority and other experts prior to declaring an emergency (unless the delay would endanger the public's health); specifies minimum information to be provided in an emergency declaration; and authorizes the suspension of ordinary State rules or regulations to facilitate emergency response. The legislature, by majority vote, may discontinue the state of emergency at any time.

The pre-declaration powers and duties are those necessary to prepare for and promptly identify a public health emergency. Under Article II ("Planning for a public health emergency"), the Public Health Emergency Planning Commission (appointed by the Governor) must prepare a plan which includes: coordination of services; procurement of necessary materials and supplies; housing, feeding, and caring for affected populations (with appropriate regard for their physical and cultural/social needs); and the proper vaccination and treatment of individuals in the event of a public health emergency.

Article III ("Measures to detect and track public health emergencies") addresses measures necessary to detect initially and then to follow a developing public health emergency, including prompt (24 hours) reporting requirements for health care providers, pharmacists, veterinarians and laboratories. Public health professionals must interview and counsel persons exposed to illnesses that may cause a public 
health emergency and their contacts. Additionally, the public health authority must investigate physical materials or facilities endangering the public's health. MSEHPA recognizes that exchange of relevant data among lead agencies is essential to assure the public's health and security. Public health, emergency management, and public safety authorities, therefore, are required to share information necessary to prevent, treat, control, or investigate a public health emergency.

The Model Act provides "special powers" that may be used only after a Governor declares a state of public health emergency. Article V ("Management of property") provides that the State's designated public health authority may close, decontaminate, or procure facilities and materials to respond to a public health emergency; safely dispose of infectious waste; and obtain and deploy health care supplies. The authorities are required to exercise their powers with respect for cultural and religious beliefs and practices, such as observing, wherever possible, religious laws regarding burial. Compensation of private property owners is provided if there is a "taking" - i.e., the government confiscates private property for public purposes (e.g., the use of a private infirmary to treat and/or isolate patients). No compensation would be provided for "nuisance abatements" - i.e., the government destroys property or closes an establishment that poses a serious health threat. This comports with the extant constitutional "takings" jurisprudence of the Supreme Court. ${ }^{51}$ If the government were forced to compensate for all nuisance abatements, it would significantly chill public health regulation.

The provisions for protection of persons found in Article VI ("Protection of persons") deal with some of the most sensitive areas within the MSEHPA. The Model Act permits public health authorities to: physically examine or test individuals as necessary to diagnose or to treat illness; vaccinate or treat individuals to prevent or ameliorate an infectious disease; and isolate or quarantine individuals to prevent or limit the transmission of a contagious disease. The public health authority also may waive licensing requirements for health care professionals and direct them to assist in vaccination, testing, examination, and treatment of patients.

While the Model Act reaffirms the authority over persons and property that health agencies have always had, it supplements these traditional public health powers with a modernized, extensive set of

${ }^{51}$ E.g., Lucas v. South Carolina Coastal Council, 505 U.S. 1003, 1004 (1992) (noting that no compensation is required under the "Takings Clause" of the Constitution for regulations that prohibit nuisances). 
conditions, principles, and requirements governing the use of personal control measures that are now often lacking in state public health law. Public health officials are explicitly directed to respect individual religious objections to vaccination and treatment. Officials must follow specified legal standards before utilizing isolation or quarantine, which are authorized only to prevent the transmission of contagious disease to others and must be by the least restrictive means available. This allows individuals, for example, to be confined in their own homes. The Model Act also affords explicit protections to persons in isolation or quarantine that go beyond most existing state laws: the public health authority is affirmatively charged with maintaining places of isolation or quarantine in a safe and hygienic manner; regularly monitoring the health of residents; and systematically and competently meeting the needs of persons isolated or quarantined for adequate food, clothing, shelter, means of communication, medication, and medical care. Orders for isolation or quarantine are subject to judicial review, under strict time guidelines and with appointed counsel; the Model Act also provides for expedited judicial relief.

Finally, the Model Act provides for a set of post-declaration powers and duties to ensure appropriate public information and communication (Article VII: "Public information regarding public health emergency"). The public health authority must provide information to the public regarding the emergency, including protective measures to be taken and information regarding access to mental health support. Experience following September $11^{\text {th }}$ and the anthrax attacks demonstrated the need for an authoritative spokesperson for public health providing comprehensible and accurate information. These events also revealed the significant mental health implications of terrorism on the population. ${ }^{52}$

The Model Act also recognizes that if government officials, health professionals, and others are to fulfill their responsibilities for preventing and responding to a serious health threat, they should not fear unwarranted liability. Consequently, MSEHPA affords persons exercising authority under the Model Act immunity from liability except for gross negligence or willful misconduct.

Taken as a whole, MSEHPA resolves a series of difficult policy debates in which the public health goals of facilitating the detection, management and containment of public health emergencies are balanced against the need to safeguard individuals' civil rights, liberties,

52 See Tara Parker-Pope, Anxious Americans Seek Antidepressants to Cope with Terror, WALL ST. J., Oct. 12, 2001, at B1 (noting a 16\% increase in new prescriptions for anti-depressants following Sept. 11). 
and property. MSEHPA is an outgrowth of a process to identify and legitimize critical public health functions against a framework of personal rights and freedoms protected by law.

\section{A. Defense of the Model Act}

There have been several specific objections to the Model Act: federalism - federal, not state, law is implicated in a health crisis; emergency declarations - the scope of a public health emergency is overly broad; abuse of power - governors and public health officials will act without sufficient justification; personal libertarianism compulsory powers over non-adherent individuals are rarely, or never, necessary; economic libertarianism - regulation of businesses is counter-productive; and safeguards of property and persons MSEHPA fails to provide strong protection of individual and economic freedoms. Before examining, and responding to, these specific objections, it will be helpful to explain the drafting process for the Model Act.

\section{Drafting Process for MSEHPA}

Days after the first cases of anthrax were confirmed on October 4, 2001 the CDC's General Counsel asked the CLPH to draft the Model Act. The assignment was to have a first draft completed within weeks, requiring an enormous expenditure of energy and resources, because governors and legislators actively sought guidance on legal reform. To meet this deadline, the CLPH was assisted by a large number of federal and state officials and scholars. The first draft of the Model Act, posted on October $23^{\text {rd }}$, borrowed from many of the best statutory provisions that existed at the state level. In this way, the Model Act would not contain radical new powers that posed a threat to civil liberties. And, MSEHPA would gain political credibility by including statutory language from the states themselves. Following release of the first draft, the Model Act was downloaded from the Center's web site tens of thousands of times, provoking considerable input by the public. MSEHPA is stronger because it was devised in a politically inclusive manner, even in the face of severe time constraints and societal fears following September $11^{\text {th }}$.

The next, and current, version of the Model Act was posted on the Center's web site on December 21, 2001. It contained a number of changes from the original draft. Critics point to the differences between the first and second versions as evidence of the problems with 
MSEHPA. ${ }^{53}$ However, the CDC and CLPH intended from the beginning to distribute the first draft widely for comment by stakeholders and the public, and to revise the Act accordingly. Discussion and comment on draft legal rules is common and expected in a deliberative democracy.

Commentators raised several points. First, community organizations expressed fears that MSEHPA could be used to restrain persons living with HIV/AIDS or could be introduced in response to an influenza epidemic. The second draft made clear that MSEHPA is not, and never was, intended for endemic diseases such as influenza or HIV/AIDS (they are not "novel" or "previously controlled or eradicated" diseases under the Act). ${ }^{54}$ Second, civil libertarians were concerned that the governor needed a greater check on his or her authority. The second draft, therefore, authorized the legislature to override a governor's declaration by a simple majority right away, rather than by a two-thirds majority after 60 days. Finally, in response to advocates who expressed concern about the Model Act's criminal penalties for disobeying an order for vaccination, treatment, or isolation, the revised Model Act removed these penalties. Instead, individuals who refused to comply with public health orders would, if necessary to protect the public's health, be subject to isolation or quarantine.

\section{Specific Objections to the Model Act}

Commentators sometimes suggest that MSEHPA affords governors unchecked power - for example, the Model Act provides a "blank check to impose the most draconian sorts of measures." 55 The Model Act, according to these reports, "puts a stranglehold on our civil liberties." 56 These assessments, however, are based on misinformation. Rather than listening to, and reporting, the experienced views of state and local health officials, the media preferred to stress the objections of a few highly vocal critics.

The Association of American Physicians and Surgeons (AAPS), a right-wing libertarian organization, for example, denounced the

53 See, e.g., Ronald Bayer \& James Colgrove, Public Health vs. Civil Liberties, 297 SCIENCE 1811 (2002) (noting the changes from the first and most recent drafts of the model act).

${ }^{54}$ The revised draft clarifies that a public health emergency applies to illnesses or health conditions that are caused by bioterrorism or the appearance of a novel or previously controlled or eradicated infectious agent or biological toxin.

${ }_{55}$ Mimi Hall, Many States Reject Bioterrorism Law; Opponents Say It's Too Invasive, USA TODAY, July 23, 2002, at A1.

${ }_{56}$ Marilyn Chase, Civil-Liberties Issues Check Plans to Counter Bioterrorism, WALL ST. J., May 17, 2002, at B1. 
Model Act, which "turns governors into dictators," permitting them to "create a police state by fiat." The Model Act, according to AAPS, "commandeered" the talent and property of the health care industry, representing a "raw assertion of power." 58 Anti-vaccination advocates attacked MSEHPA for authorizing mandatory vaccination. These groups have opposed all forms of compulsory public health powers, including school vaccination requirements. ${ }^{59}$ Finally, Boston University faculty members described the Model Act as "the old soviet model of public health (lots of power and no standards for applying it). " its response to MSEHPA: "Unaccountable and untrustworthy public health agencies are not only ineffective, they can ... destroy both life and civil liberties." 61

Critics' claims that MSEHPA does not have wide support are untrue. During the single legislative session since its December 21, 2001 release, 36 states and the District of Columbia introduced legislation based in whole or part on MSEHPA. Of these, 20 states and the District of Columbia passed bills. ${ }^{62}$ Virtually all the rest of the states used the Model Act in less formal ways to assess the adequacy of their own laws and policies. Thus, states heeded the advice of Secretary for Health and Human Services Tommy Thompson who asked officials to use the Model Act as a yardstick against their own legislation. ${ }^{63}$ To further facilitate this process, the National Conference of State Legis-

57 Ass'N OF AM. PHYSICIANS AND SURgeons, AAPS ANALYSIS: MODEL Emergency Health Powers Act (MEHPA) Turns Governors into Dictators (2001), available at http://www.aapsonline.org/testimony/emerpower.htm (Dec. 3, 2001).

${ }^{58} \mathrm{Id}$.

${ }^{59}$ See, e.g., Press Release, National Vaccine Information Center, Vaccine Safety Advocates Warn of Risks of Proposed Mass Smallpox Vaccination Policy (Oct. 7, 2002), available at http://www.909shot.com/PressReleases/prsmallpoxpolicy.htm (providing reasons for not prematurely vaccinating the population against smallpox).

${ }^{60}$ Letter from Boston area health law teachers to CLPH (Nov. 1, 2001).

${ }^{61}$ George J. Annas, Bioterrorism and Civil Liberties, 347 NEW ENG. J. MED. 856,857 (2002).

${ }_{62}$ Center for Law and the Pub's. Health at Georgetown and Johns Hopkins Univs., supra note 6 (describing relevant legislation).

${ }_{63}^{6}$ See Justin Gillis, States Weighing Laws to Fight Bioterrorism, WASH. Post, Nov. 19, 2001, at A1 (mentioning that the Model Act had the backing of Tommy Thompson, who specifically said, "[w]e need not only a strong health infrastructure and a full stockpile of medical resources, but also the legal and emergency tools to help our citizens quickly"). 
latures prepared a formal checklist of powers based on the Model Act. ${ }^{64}$

The inflammatory rhetoric against MSEHPA may be useful politically, but seriously mischaracterizes the Act and misleads the public. Governors are not afforded plenary powers but have significant checks and balances; vaccination is not a radical new power, but is common in state law ${ }^{65}$ and constitutionally approved by the Supreme Court. ${ }^{66}$ MSEHPA is not at all analogous to old Soviet law, but has clear standards and procedures for the exercise of powers. Indeed, nothing within MSEHPA is "extraordinary" or an unreasonable threat to civil liberties. To the contrary, MSEHPA provides safeguards of personal liberty that do not exist in most state statutes, as the following discussion demonstrates.

\section{Federalism}

Critics argue that acts of terrorism are inherently federal matters, eliminating the need for expansion of state public health powers. ${ }^{67}$ It is certainly true that federal authority is extraordinarily important in responding to catastrophic public health events. For example, bioterrorism may trigger national security concerns, require investigation of federal offences, and affect geographic regions beyond state perimeters or even the entire country. Consequently, the federal government often takes a leading role in responding to a public health emergency, as they did in the anthrax outbreaks. ${ }^{68}$

Indeed, the federal government, under the national defense or commerce powers of the Constitution, is entitled to act in the context

${ }^{64}$ LISA SPEISSEgGer \& CHERYL RUNYON, NAT'L CONFERENCE OF STATE Legislatures, THe Model State Emergency Health Powers ACt: A CheCKList OF ISSUES (2002).

${ }_{65}$ See James G. Hodge, Jr. \& Lawrence O. Gostin, School Vaccination Requirements: Historical, Social, and Legal Perspectives, KY.L.J. 831, 851 (20012002) (discussing the historical development of school vaccine requirements in state law).

${ }^{66}$ Jacobson v. Massachusetts, 197 U.S. 11, 31 (1905) (holding that public health responses were within a state's police power unless the statute has "no real or substantial relation" to public health, public morals, or public safety or the statute is, "beyond all question, a plain, palpable invasion of rights secured by the fundamental law").

${ }^{67}$ See, e.g., George J. Annas, Bioterrorism, Public Health, and Civil Liberties, 346 NEW ENG. J. MED. 1337 (2002) (criticizing the Model State Emergency Health Powers Act).

${ }^{68}$ Federal agencies such as the CDC, the Federal Bureau of Investigation, and the Department of Homeland Security are centrally important in averting and containing bioterrorism. 
of multi-state threats to health and security. ${ }^{69}$ However, states have "plenary" authority to protect the public's health under their reserved powers in the Tenth Amendment. The Supreme Court has made clear that states have a deep reservoir of public health powers, conceiving of state police powers as an "immense mass of legislation [in which] [i]nspection laws, quarantine laws, [and] health laws of every description ... are component [s] of this mass." ${ }^{70}$ The Supreme Court, moreover, has regarded federal police powers as constitutionally limited, and has curtailed the expansion of national public health authority. ${ }^{71}$

The assertion of federal jurisdiction, of course, does not obviate the need for adequate state and local public health power. ${ }^{72}$ States and localities have been the primary bulwark of public health in America. From a historical perspective, local and state public health agencies pre-dated federal agencies. Local Boards of Health were in operation in the late 18th Century and state agencies emerged after the Civil War. Federal health agencies, however, did not develop a major presence until Franklin Delano Roosevelt's New Deal. State and local agencies have played a crucial role in infectious disease control from colonial and revolutionary times, through the industrial revolution, to the modern times. ${ }^{73}$

From an economic and practical perspective, most public health activities take place at the state and local level - e.g., surveillance, communicable disease control, and food and water safety. States and localities probably would be the first to detect and respond to a health emergency and would have a key role throughout. This requires states to have effective, modern statutory powers that enable them to work along side federal agencies. It does not matter which governmental entity (federal or state) has the primary responsibility in any given case. What is important is that both levels of government operate with adequate resources and sound legal foundations.

${ }^{69}$ See U.S. ConST. art. I, $\S 8$, cl. 1,3 (giving Congress the authority to tax and regulate commerce). See also United States v. Sullivan, 332 U.S. 689, 696, 698 (1948) (upholding Congress' authority to prohibit misbranding of drugs under its interstate commerce powers).

${ }^{70}$ Gibbons v. Ogden, 22 U.S. (9 Wheat.) 1, 203 (1824).

${ }^{71}$ See United States v. Lopez, 514 U.S. 549, 566-68 (1995) (striking down a federal statute prohibiting guns in school zones as an unlawful expansion of Congress' commerce clause powers).

72 See Michael Moser, Bioterrorism and Civil Liberties, 347 NEW ENG. J. MED. 856 (2002) ("Historically and legally, state and local public health agencies in this country have had the lead role in responding to outbreaks or suspected outbreaks of communicable disease within their jurisdictions").

${ }_{73}$ See Gostin, supra note 5, at 242-48 (chronicling the rise of local authority over matters of public health). 
4. Declaration of a Public Health Emergency

Critics express concern that the Model Act could be triggered too easily, creating a threat to civil liberties. As mentioned above, community-based organizations originally objected to the idea that a Governor might declare a public health emergency for an endemic disease such as HIV/AIDS or influenza. Although this may have been a problem with the initial version of the Model Act, the current version virtually excludes HIV/AIDS and influenza through its requirement that a disease must be "novel or previously controlled or eradicated."

Legal scholars express concerns that a Governor could declare an emergency for theoretical or low-level risk. However, the drafters set demanding conditions for a Governor's declaration, clearly specifying the level of risk. A public health emergency may be declared only in the event of bioterrorism or the appearance of a novel or previously controlled or eradicated infectious agent or biological toxin that poses a high probability of a large number of deaths or serious disabilities. Indeed, the drafters rejected arguments from high-level federal and state officials to set a lower threshold for triggering a health emergency.

Finally, commentators suggest that Governors retain too much discretion to declare a public health emergency. Yet, the Model Act specifies clear criteria for triggering Gubernatorial powers and uses language that fetters the exercise of discretion. As noted below, the Model Act also allows the legislature and judiciary to intervene if the Governor has acted outside the scope of his or her authority. Taken as a whole, the drafters carefully limit the circumstances when the more robust powers of the Model Act can be invoked.

\section{Governmental Abuse of Power}

Critics argue that Governors and public health authorities would abuse their authority and exercise powers without justification. This kind of generalized argument could be used to refute the exercise of governmental power in any realm because executive branch officials may over-reach. However, such general objections have never been a reason to deny government the power to avert threats to health, safety, and security. The answer to such general objections is to introduce into the law careful safeguards to prevent officials from acting outside the scope of their authority. The Model Act builds in effective protection against governmental abuse. It adopts the doctrine of separation of powers, so that no branch wields unchecked authority. These checks and balances offer a classic means of preventing abuse.

The Model Act creates several hedges against abuse: (1) the Governor may declare an emergency only under strict criteria and, if 
feasible, with careful consultation with public health experts and the community; (2) the legislature, by majority vote, can override the Governor's declaration at any time; and (3) the judiciary can terminate the exercise of power if the Governor violates the standards or procedures of the Model Law or acts unconstitutionally. No law can guarantee that the powers it confers will not be abused. Much depends on the wisdom of judges, the competency of health officials, and the vigilance of a free citizenry. But MSEHPA counterbalances executive power by providing a strong role for the legislature and judiciary. The Model Act modernizes antiquated law and replaces it with clear criteria, fair procedures, and robust entitlements that are conspicuously absent from infectious disease statutes in the United States. There is little more that any law could do to prevent abuse of power.

\section{Personal Libertarianism}

Critics imply that the Model Law should not confer compulsory power at all. In particular, they object to compulsory powers to isolate or quarantine. Commentators reason that services are more important than power; that individuals will comply voluntarily with public health advice; and that tradeoffs between civil rights and public health are not required and even are counterproductive. Before responding to these criticisms, it is important to recognize that the Model Act does not permit public health officials to vaccinate, test, or medically treat people against their will. At most, individuals may be isolated or quarantined to reduce their risk to others.

Certainly the HIV/AIDS epidemic has demonstrated that public health and civil liberties can be mutually reinforcing - respect for individual freedoms can promote the public's health. ${ }^{74}$ The CDC's approach to legal preparedness for bioterrorism, moreover, stresses the importance of community education and involvement in planning. ${ }^{75}$ The goal is to facilitate public cooperation in the event of a health crisis. Despite the undoubted importance of voluntarism, there still remains a residual need for compulsory powers.

First, although the provision of services may be more important than the exercise of power, the state undoubtedly needs a certain

${ }^{74}$ See Jonathan Mann et al., Health and Human Rights, 1 J. HEALth \& HUMAN RIGHTS 6, 20-21 (1994) (“. . . HIV/AIDS may be illustrative of a more general phenomenon in which individual and population vulnerability to disease, disability, and premature death is linked to the status of respect for human rights and dignity").

${ }^{75}$ Ctrs. for Disease Control \& Prevention, Public Health legal PREPAREDNESS Program (July 17, 2002) (unpublished). 
amount of authority to protect the public's health. Government must have the power to prevent individuals from endangering others. It is only common sense, for example, that a person who has been exposed to an infectious disease should be required to be isolated if necessary to prevent transmission to family, friends, or the community.

Second, although most people can be expected to comply willingly with public health measures because it is in their own interests and/or desirable for the common welfare, not everyone will comply. Individuals may resist loss of autonomy, privacy, or liberty even if their behavior threatens others. Provided that public health powers are hedged with safeguards, individuals should be required to yield some of their interests to protect the health and security of the community.

Finally, although public health and civil liberties may be mutually enhancing in many instances, they sometimes come into conflict. When government acts to preserve the public's health, it can interfere with property rights (e.g., freedom of contract, to pursue a profession, or to conduct a business) or personal rights (e.g., autonomy, privacy, and liberty). The history of public health is littered with illustrations of trade offs between public health and civil liberties. ${ }^{76}$ It may be fashionable to argue that there is no tension, but public health officials need to make hard choices particularly in public health emergencies.

Individuals whose movements pose a significant risk of harm to their communities do not have a "right" to be free of interference necessary to control the threat. There simply is no basis for this argument in constitutional law, and perhaps little more in political philosophy. Even the most liberal scholars accept the harm principle - that government should retain power to prevent individuals from endangering others. ${ }^{77}$

The Supreme Court has been equally clear about the limits of freedom in a constitutional democracy. The rights of liberty and due process are fundamental but not absolute. Justice Harlan in the foundational Supreme Court case of Jacobson v. Massachusetts wrote: "There are manifold restraints to which every person is necessarily subject for the common good. On any other basis organized society could not exist with safety to its members." ${ }^{178}$ Critics argue, without support from any judicial authority, that the Supreme Court's land-

${ }^{76}$ See, e.g., Gostin, supra note 5, at 113-308 (providing examples of privacy, freedom of expression, bodily integrity, commercial regulation, and tort litigation-based trade-offs); GosTin, supra note 30.

77 Joel Feinberg, The Moral Limits of the Criminal Law, 4 vols. (19871990).

78 Jacobson v. Massachusetts, 197 U.S. 11, 26 (1905). 
mark decision in Jacobson, reiterated by the Court over the last Century, is no longer apposite. There is, according to this line of argument, a constitutional right to refuse interventions even if the individual poses a public risk. Yet, the courts have consistently upheld compulsory measures to avert a risk, ${ }^{79}$ including the power to compulsorily test ${ }^{80}$ report ${ }^{81}$ vaccinate, ${ }^{82}$ treat, ${ }^{83}$ and isolate ${ }^{84}$ provided there are clear criteria and procedures. Certainly, courts will use a higher standard if public health authorities tread on touchstones of personal liberty such as the right to travel or bodily integrity. ${ }^{85}$ Nevertheless, if the state is responding to a demonstrable risk and adopts means reasonably calculated to avert the harm, there is ample support in philosophic theory and constitutional law to support the intervention. ${ }^{86}$

\section{Economic Libertarianism}

Civil libertarians have not been the only group to critique the Model Act. Businesses, as well as law and economic scholars, complain that MSEHPA interferes with free enterprise. Most economic stakeholders including the food, transportation, pharmaceutical, and health care industries lobbied legislators and CLPH faculty. These groups argue that they should not be compelled to share data with government, abate nuisances, destroy property, and provide goods and services without their express agreement. ${ }^{87}$

Generally speaking, the Model Law provides several kinds of powers to regulate businesses: destruction of dangerous or contaminated property, nuisance abatements, and confiscation of property for

${ }^{79}$ See, e.g., Washington v. Harper, 494 U.S. 210, 227 (1990) (upholding forced administration of antipsychotic medication if the inmate is dangerous to himself or others and the treatment is in the inmate's medical interest).

${ }_{80}^{80}$ Skinner v. Ry. Labor Executives' Ass'n, 489 U.S. 602 (1989).

${ }^{81}$ Whalen v. Roe, 429 U.S. 589 (1977).

82 Zucht v. King, 260 U.S. 174 (1922).

${ }^{83}$ See McCormick v. Stalder, 105 F.3d 1059, 1061 (5th Cir. 1997) (finding the state's compelling interest in reducing the spread of tuberculosis justified involuntary treatment).

${ }^{84}$ See Greene v. Edwards, 263 S.E.2d 661 (1980) (recognizing the authority of the state to involuntarily commit a person afflicted with certain communicable diseases).

${ }^{85}$ See Scott Burris, Rationality Review and the Politics of Public Health, 34 VILL. L. REV. 933, 935-37 (1989) (noting that numerous law review articles assert that, in contrast with Jacobson, strict scrutiny applies to public health laws to the extent that they interfere with fundamental liberties).

${ }_{86}$ See Gostin, supra note 5, at 99-100 (describing the government's burden to evaluate its regulation of public health measures).

87 Sarah Lueck, States Seek to Strengthen Emergency Powers: Movement is Raising Privacy and Civil-Liberties Concerns, WALL ST. J., Jan. 7, 2002, at A26. 
public purposes. All of these powers have been exercised historically and comply with constitutional and ethical norms. If businesses have property that poses a public threat, government has always had the power to destroy that property. ${ }^{88}$ For example, if a rug were contaminated with anthrax or smallpox, government would certainly have the power to order its destruction.

Similarly, if businesses are engaged in an activity that poses a health threat, government has always had the power to abate the nuisance. ${ }^{89}$ Businesses must comply with all manner of health and safety regulations that interfere with economic freedoms. ${ }^{90}$ Those who believe in the undeterred entrepreneur may not agree with health regulations, but they are necessary to ensure that business activities to not endanger the public.

Finally, government has always had the power to confiscate private property for the public good. ${ }^{91}$ In the event of bioterrorism, for example, it may be necessary for the state to have adequate supplies of vaccines or pharmaceuticals. Similarly, government may need to use health care facilities for medical treatment or quarantine of persons exposed to infection.

Businesses argue that government should not have broad powers to control enterprise and property. If these powers have to be exercised, businesses want to ensure they are compensated according to market values. The Model Act follows a classical approach to the issue of property rights. Compensation of property owners is provided if there is a "taking" - i.e., the government confiscates private property for public purposes (e.g., the use of a private infirmary to treat and/or isolate patients). No compensation would be provided for "nuisance abatements" - i.e., the government destroys property or closes an establishment that poses a serious health threat. This com-

${ }^{88}$ E.g., Perepletchikoff v. City of Los Angeles, 345 P.2d 261 (Cal. Dist. Ct. App. 1959) (holding that the city has the authority to demolish hotel to abate a nuisance).

${ }^{89}$ E.g., City of New York v. New St. Mark's Baths, 562 N.Y.S.2d 642, 643 (App. Div, 1990) (upholding closure of bathhouses to abate a public health nuisance); Burns v. Mayor and City Council of Midland, 234 A.2d 162, 165 (Md. 1967) (noting that the legislature unquestionably has the authority to require the removal of a structure found to endanger public health).

${ }_{90}$ E.g., Slaughter-House Cases, 83 U.S. 36, 81 (1873) (upholding sanitary regulations of slaughter-houses). See also, William J. Novak, THE PEOPLE'S WELFARE: LAW AND REGULATION IN NINETEENTH-CENTURY AMERICA (1996).

${ }^{91}$ See, e.g., Loretto v. Teleprompter Manhattan CATV Corp., 458 U.S. 419 (1982) (upholding statute that require private property owners to permit cable TV operators to place cable on their premises provided that they are justly compensated for the occupation). 
ports with the extant constitutional "takings" jurisprudence of the Supreme Court. ${ }^{92}$ If the government were forced to compensate for all nuisance abatements, it would significantly chill public health regulation.

In American history and constitutional law, private property has always been held subject to the restriction that it not be used in a way that posed a health hazard. As Lemuel Shaw of the Massachusetts Supreme Judicial Court observed as early as 1851: "We think it settled principle, growing out of the nature of well ordered civil society, that every holder of property ... holds it under the implied liability that it shall not be injurious to the rights of the community." ${ }^{93}$

\section{Safeguards of Persons and Property}

The real basis for debate over public health legislation should not be that powers are given, because it is clear that power is sometimes necessary. The better question is whether the powers are hedged with appropriate safeguards of personal and economic liberty. The core of the debate over the Model Act ought to be whether it appropriately protects freedoms by providing clear and demanding criteria for the exercise of power and fair procedures for decision-making. It is in this context that the attack on MSEHPA is particularly exasperating because critics rarely point to areas where the standards and procedures in MSEHPA could be strengthened. Nor do they compare the safeguards in the Model Act to those in extant public health legislation.

It is important to note that powers over individuals (e.g., testing, physical examination, treatment, and isolation) and businesses (e.g., nuisance abatements and seizure or destruction of property) already exist in state public health law. These powers have been exercised since the founding of the Republic. ${ }^{94}$ MSEHPA, therefore, does not contain new, radical powers over the individual. Most tellingly, the Model Act contains much better safeguards of individual and economic liberty than appear in communicable disease statutes enacted in the early-to-mid $20^{\text {th }}$ Century.

92 See, e.g. Lucas v. S.C. Coastal Council, 505 U.S. 1003, 1027 (1992) (finding that the government may only deprive an individual of all economic uses of his or her property without compensation when the owner's use of property were not originally part of his title).

${ }_{93}$ Commonwealth v. Alger, 61 Mass (7 Cush.) 53, 84-85 (1851).

${ }^{94}$ See, e.g., James A. Tobey, Public Health LaW (1939); Leroy Parker \&

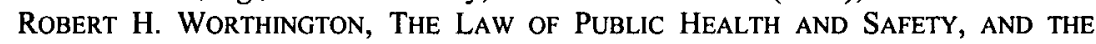
POWERS AND DUTIES OF BOARDS OF HEALTH, at xxxviii-xxxix (1892). 
Unlike older statutes, MSEHPA provides clear and objective criteria for the exercise of powers, rigorous procedural due process, respect for religious and cultural differences, and an explicit set of entitlements for humane treatment. First, the criteria for the exercise of compulsory powers are based on the modern "significant risk" standard enunciated in constitutional law and disability discrimination law. The Model Act also requires public health officials to adopt the "least restrictive alternative." Second, the procedures for intervention are rigorous, following the most stringent requirements set by the Supreme Court, including the right to counsel, presentation and cross examination of evidence, and reasons for decisions. Third, the Model Act shows toleration of vulnerable groups through its requirements to respect cultural and religious differences whenever consistent with the public's health. Finally, the Model Act provides a new set of rights to care and treatment of persons subject to isolation or quarantine. These include the right to treatment, clothing, food, communication, and humane conditions.

In summary, MSEHPA provides a modern framework for effective identification and response to emerging heath threats, while demonstrating respect for individuals and toleration of groups. Indeed, the CLPH agreed to draft the law only because a more draconian approach might have been taken by governments acting on their own and responding to public fears and misapprehensions. ${ }^{95}$

\section{RE-THINKING THE PUBLIC GOOD}

American values at the turn of the $21^{\text {st }}$ century fairly could be characterized as individualistic. There was a distinct orientation toward personal and proprietary freedoms and against a substantial government presence in social and economic life. The attacks on the World Trade Center and Pentagon and the anthrax outbreaks reawakened the political community to the importance of public health. Historians will look back and ask whether September $11^{\text {th }}, 2001$ was a fleeting scare with temporary solutions or whether it was a transforming event.

There are good reasons for believing that resource allocations, ethical values, and law should transform to reflect the critical importance of the health, security and well being of the populace. It is not that individual freedoms are unimportant. To the contrary, personal liberty allows people the right of self-determination, to make judg-

${ }^{95}$ See generally David Cole, Enemy Aliens, 54 STAN. L. REv. 953 (2002) (noting numerous examples where the Bush Administration has sacrificed the civil liberties of non-citizens in response to September $11^{\text {th }}$ ). 
ments about how to live their lives and pursue their dreams. Without a certain level of health, safety, and security, however, people cannot have well-being; nor can they meaningfully exercise their autonomy or participate in social and political life.

My purpose is not to assert which are the more fundamental interests: personal liberty or health and security. Rather, my purpose is to illustrate that both sets of interests are important to human flourishing. The Model State Emergency Health Powers Act was designed to defend personal as well as collective interests. But in a country so tied to rights rhetoric on both sides of the political spectrum, any proposal that has the appearance of strengthening governmental authority was bound to travel in tumultuous political waters. 